\title{
Effect of Nursing Satisfaction Level on Service Quality at Inpatient Installation in X Hospital
}

\author{
Nur Fadilah Dewi ${ }^{1 *}$, Radityo Kusumo Santoso ${ }^{2}$ \\ ${ }^{1}$ Hospital Administration Department, Vocational Education Program, \\ Universitas Indonesia \\ ${ }^{2}$ Office \& Secretary Administration Department, Vocational Education Program, Universitas Indonesia \\ *E-mail: dewifadilah08@gmail.com
}

\begin{abstract}
A hospital's success is determined not only by its profitability but also by patient and provider satisfaction. Provider satisfaction affects the quality of patient services. In a hospital setting, nurses have the most hours of contact with the patient as nurses are on call 24 hours a day. For this reason, the role of nurses is particularly important in determining patient satisfaction and in making a hospital successful and competitive. The aim of this study is to examine the relationship between level of nursing satisfaction and quality of nursing services using questionnaires.
\end{abstract}

Keywords: service quality, performance, nurse satisfaction, hospital

\section{Introduction}

To be successful, a hospital must offer high-quality service in keeping with consumer expectations. Advances in technology and science have changed the public's perception of health services in hospitals. In addition to the quality of the professional care services they receive, patients also consider the quality of their interpersonal interactions with providers when evaluating their hospital experience. The perceived quality of these interactions can be improved by building trust between patients and providers.

The quality of the services received during treatment as perceived by the patient is closely related to the human resources of the nursing staff, as nurses are on call 24 hours a day to assist each patient. One factor that can affect quality of services is job satisfaction among nurses. Compensation has a significant impact on nurses' performance, but good leadership greatly enhances the effect of adequate compensation on nurses' performance. Nursing managers must have the ability to manage resources, engage in effective marketing, communicate and negotiate effectively, and motivate and influence others (Armanu, 2017).

High levels of motivation and job satisfaction as well as a positive work environment have significant positive effects on employee performance (Al Aluf, Sudarsih, Musmedi, \& Supriyadi, 2017). This means that improving job satisfaction among the employees of Asembagus Hospital in Indonesia should improve employee performance.

Because hospitals offer various levels of service including inpatient, outpatient, and emergency services, there is often some degree of ambiguity regarding the nurse's role in each of these settings. This ambiguity can cause conflict and reduce job satisfaction, self-efficacy and nurse adaptability (Kadir, Kamariah, \& Saleh, 2017).

A previous study regarding emergency departments has shown that patient satisfaction with nursing care depends on wait time, precautions taken to protect the patient's safety, the ability of the staff to communicate that they care about the patient as a person and the empathy conveyed by the healthcare provider. Patient satisfaction with emergency room doctors, on the other hand, is more dependent on hygiene, pain management, wait time, and satisfaction with nursing care than on the doctors' treatment recommendations. Cleanliness and efficiency in emergency room conferences are also associated with increased patient satisfaction (Newcomb et al., 2017). hospitals.

Building on this background, the present study investigates satisfaction levels among nurses working in

\section{Literature Study}

\subsection{Job Satisfaction}

Job satisfaction is the most complex challenge that many managers face, partly due to its intangible nature as an emotional response. Many studies have shown that job satisfaction has a significant impact on worker motivation, which in turn has an impact on productivity. Nevertheless, many companies still pay minimal attention to employee satisfaction. 
Job satisfaction has been defined as an employee attitude consisting of positive feelings about one's work that results from the characteristics of the work environment. A person with a high level of job satisfaction will have positive feelings about their work, while a person who is not satisfied with their work will have negative feelings about it.

It has been suggested that job satisfaction relates to the positive and negative attitudes of employees to the work performed by the individual and the inner conditions of the mind. If a person responds positively to his or her work, he or she will feel satisfied. The level of job satisfaction depends on the difference between what a person actually does in his or her work and what is expected of his job.

a. Factors that Affect Job Satisfaction:

1) Need fulfillment

Satisfaction is determined by the ability of the job's characteristics to allow individuals to meet their needs.

2) Discrepancies

The fulfillment of expectations reflects the difference between what the individual expects to get from his or her job and what he or she actually gets from it. When expectations expect more than they receive, they are dissatisfied. Individuals are satisfied, in contrast, when they receive benefits beyond their expectations.

3) Value attainment

The result of function perception offers an important interpretation of individual work values.

4) Equity

Satisfaction is influenced by how fairly individuals are treated at work.

5) Genetic components

b. Determinants of Job Satisfaction

1) The work itself

There is a statistically significant relationship between job satisfaction and the job itself. The results of other studies have indicated that this dimension can produce satisfaction or dissatisfaction.

2) Supervision

Supervision is the key to job satisfaction in terms of the supervisor's ability to provide emotional and technical support and guidance in work-related tasks. Relationships with immediate supervisors are an important antecedent of employee satisfaction in the workplace.

3) Workers

The theory of social networks has shown that social support of peer networks is a resource that affects job satisfaction. Some authors have found that having friendly colleagues and support contributes to greater job satisfaction.

4) Promotion

Some researchers have argued that job satisfaction is strongly associated with promotion opportunities. The positive relationship between promotion and job satisfaction depends on perceived equity among employees, however.

5) Wages/salary

Salary satisfaction is a major concern for employers and employees. For employees, wages are clearly important as they allow employees to meet their economic needs. It is important that they are satisfied with their overall salary, as this can affect their attitudes and behavior. Employee dissatisfaction with paychecks, for example, can reduce work engagement, increase theft, and catalyze turnover.

c. The Inpatient Setting

In hospitals, intramural services play a central role which is very important when performing professional services. Hospitalization is offered to incoming patients with a view to observation, diagnosis, therapy, medical rehabilitation and/or other medical services. The inpatient setting is for patients who need to be treated for more than 24 hours.

d. Factors that Correlate with Job Satisfaction

1) Motivation

2) Job involvement

3) Organizational citizenship behavior

4) Organizational commitment

5) Absenteeism

6) Turnover 
7) Feeling stress

8) Work performance

\subsection{Performance}

Performance is the measure of how well the global resources that exist within an organization are achieving the organization's goals, with regard to both quantity and quality. Performance appraisal is an organizational method of evaluating employees in the performance of their work.

\subsection{Service Quality}

Hospitals as service providers play a very strategic role in improving the state of public health. As a result, hospitals are required to provide the best possible services in accordance with established standards as their performance can affect the entire community.

Quality of service has been defined as the difference between the actual or perceived level of service that is received and the level of service that is expected or desired. If the service received is more than what was expected, we can say that the service is eligible or satisfactory. If the service received is not as expected or less than expected, then it is not eligible. In addition, quality of service can be measured based on actual dimensions, reliability, responsiveness, confidence, and empathy, using a comparative three-point scale to assess differences between performance expectations and perceptions (Rivai, 2010).

\section{Methods}

This descriptive study was conducted in May 2018 at the hospital unit known as RS X. The study population was all inpatient nurses working at hospital X, constituting a study population of 37 individuals.

\section{Results}

We distributed questionnaires among the inpatient nurses and obtained the following results:

Table 1 Frequency Distribution of Employee Satisfaction Internal RS X Year 2018

\begin{tabular}{|c|c|c|c|c|}
\hline No. & Variables & $\begin{array}{l}\text { Score } \\
\text { Reality }\end{array}$ & $\begin{array}{l}\text { Score } \\
\text { of } \\
\text { Hope }\end{array}$ & $\begin{array}{l}\text { Satisfaction } \\
\text { Level }(80-90 \% \\
\text { standard score) }\end{array}$ \\
\hline 1. & Hospitals pay my salary according to my responsibilities & 54 & 107 & $49,6 \%$ \\
\hline 2. & Hospitals involve employees in making decisions & 81 & 116 & $69,8 \%$ \\
\hline 3. & Hospitals always provide information needed by employees & 92 & 138 & $66,7 \%$ \\
\hline 4. & Hospitals provide incentives according to my workload & 82 & 144 & $56,9 \%$ \\
\hline 5. & Hospitals provide uniforms for employees every year & 79 & 129 & $61,2 \%$ \\
\hline 6. & $\begin{array}{l}\text { The hospital provides equipment for patient and employee } \\
\text { safety }\end{array}$ & 100 & 143 & $70 \%$ \\
\hline 7. & Hospitals provide health insurance to employees & 105 & 142 & $74 \%$ \\
\hline 8. & Hospitals provide a comfortable working space for employees & 103 & 142 & $72,5 \%$ \\
\hline 9. & Hospitals provide workplace accident insurance to employees & 84 & 145 & $58 \%$ \\
\hline 10. & Coworkers give me enough support in my work & 107 & 124 & $86 \%$ \\
\hline 11. & My boss treats his subordinates well & 105 & 137 & $76,6 \%$ \\
\hline 12. & My superiors' praise, suggestions, and ideas are satisfactory & 101 & 134 & $75,4 \%$ \\
\hline 13. & $\begin{array}{l}\text { Problem solving is discussed by the employer together with } \\
\text { the employee }\end{array}$ & 90 & 131 & $68,7 \%$ \\
\hline 14. & $\begin{array}{l}\text { The employer offers opportunities to advance in the hospital } \\
\text { organization }\end{array}$ & 94 & 119 & $79 \%$ \\
\hline 15. & Hospitals provide promotions for outstanding employees & 86 & 130 & $66,2 \%$ \\
\hline 16. & $\begin{array}{l}\text { The hospital provides opportunities to continue education for } \\
\text { outstanding employees }\end{array}$ & 72 & 128 & $56,3 \%$ \\
\hline 17. & Hospitals provide an opportunity for capable employees to & 84 & 120 & $70 \%$ \\
\hline
\end{tabular}




\begin{tabular}{|c|c|c|c|c|}
\hline & advance to higher positions & & & \\
\hline 18. & $\begin{array}{l}\text { Superiors offer opportunities to try new ways and methods of } \\
\text { performing work tasks }\end{array}$ & 79 & 126 & $62,7 \%$ \\
\hline 19. & $\begin{array}{l}\text { The hospital gives opportunities to add skills through seminars } \\
\text { and training }\end{array}$ & 86 & 141 & $61 \%$ \\
\hline 20 & Hospitals allow time for employee leave & 88 & 142 & $62 \%$ \\
\hline
\end{tabular}

As Table 1 shows, the level of employee satisfaction is still low in general. Based on our questionnaire results, the average satisfaction level is $67.13 \%$, whereas the standard is $80-90 \%$. The factor with which nurses were most satisfied was the support provided by their coworkers: $86 \%$ of employees felt satisfied with their coworker support. The factor with which nurses were least satisfied was the salary's ability to meet the employees' needs and responsibilities: only $49.6 \%$ were satisfied with their salary.

\section{Discussion}

\subsection{Level of Satisfaction among Nursing Employees}

Some elements of employee satisfaction include:

1) Involvement in decision-making

2) Recognition for doing a good job

a) Access to sufficient information to do the job well, active encouragement to be creative and use initiative, and adequate support.

b) Overall satisfaction with the company.

The percentages of employee satisfaction in our survey represent the percentages of employees who expressed satisfaction with each factor and are in favor of the hospital's performance in each area. Improved employee satisfaction with the availability of performance support can improve the performance and quality of hospital services. The employee satisfaction standard set by the Directorate General of Medical Services is $90 \%$. As the overall job satisfaction rate at the hospital in our study was only $67.13 \%$, there is some room for improvement.

\section{Conclusion}

Employee satisfaction can affect the performance of nurses in providing services. Our survey results reveal a high degree of employee dissatisfaction with hospital salaries. Yet job satisfaction, especially among young employees, derives not only from a high salary but also from opportunities to develop themselves and continue on a clear career path. Job satisfaction is thus not entirely dependent on the size of one's salary, but most of the nurses said that the bigger their salary, the higher their satisfaction and loyalty to the hospital would be. These factors are important to the success of the hospital.

\section{References}

Al Aluf, W., Sudarsih, S., Musmedi, D. P., \& Supriyadi, S. (2017). Assessing the impact of motivation, job satisfaction, and work environment on the employee performance in healthcare services International Journal of Scientific \& Technology, 6(10).

Armanu, A. (2017). The role of shared leadership and work environment in strengthening the influence of compensation on nurse's performance, European Research Studies, 20(3A), 82.

Azar, I. (2017). Evaluating health service quality: using importance-performance analysis, International Journal of Health Care Quality Assurance, 30(7), 656-663.

Connolly, D., \& Wright, F. (2017). The nursing quality indicator framework tool. International Journal of Health Care Quality Assurance, 30(7), 603-616.

Harper, E., Castrucci, B. C., Bharthapudi, K., \& Sellers, K. (2015). Job satisfaction: A critical, understudied facet of workforce development in public health. Journal of Public Health Management and Practice, 21(Suppl 6), S46-S55.

Kadir, A. R., Kamariah, N., \& Saleh, A. (2017). The effect of role stress, job satisfaction, self-efficacy and nurses' adaptability on service quality in public hospitals of Wajo, International Journal of Quality and Service Sciences, 9(2), 184-202.

Muhith, A. (2016). Nursing service quality model based on nursing performance and patient satisfaction analysis in Gresik District Hospital. Journal of Health, Medicine and Nursing, 23. Retrieved from https://iiste.org/Journals/index.php/JHMN/article/view/29036

Newcomb, P., Wilson, M., Baine, R., McCarthy, T., Penny, N., Nixon, C., \& Orren, J. (2017). Influences on 
patient satisfaction among patients who use emergency department frequently for pain-related complains, Journal of Emergency Nursing, 43(6), 553-559.

Veithzal, R., et al. Corporate Performance Management from theory to practice, The Right and Simple Solution to Advance Companies by Gathering Company Performance, 2010. 